\title{
Establishing porosity and bulk density analysis effect on foundation and fexible pavement in heterogeneous sand and silty formation
}

\begin{abstract}
The papers express the relationship between bulk density and soil porosity, such analysis were carried out to evaluated there structure refection on the porosity and bulk density in sandy and silty clay formation, these expression are mostly applied for geotechnical investigation including design and construction for flexible pavement. The generated values for bulk density and porosity range from $2.56-2.68,0.27$ $0.18,2.5-2.63,0.23-0.17,2.52-2.64,0.22-0.27,2.72-2.65,0.12-0.19,2.51-2.64$, $0.28-0.270,0.2-2.5,2.54-2.680 .27-0.18,2.5-2.63,0.23-0.17,2.57-2.64,0.22-0.27$, $2.71-2.650 .12-0.19,2.51-2.58,0.28-0.26$; The behaviour of the soil shows that the higher the bulk density the lower the porosity while in some condition it is vice-versa, this paper has express the relationship between porosity and bulk density. Moreso the study observed that the higher the bulk density the lower the porosity, these are the parameters significant on the geotechnical investigation for foundation and other constructive activities, these condition express the behaviour of sandy and silty clay formation in deltaic depositions, the behaviour of these soil are problematic in the construction of foundation and flexible pavement.
\end{abstract}

Keywords: bulk density, porosity, foundation, flexible pavement
Volume 2 Issue I - 2018

\author{
Eluozo SN,' Oba $\mathrm{AL}^{2}$ \\ 'Department of Civil Engineering College of Engineering, \\ Gregory University Uturu, Nigeria \\ ${ }^{2}$ Department of Civil Engineering, Ken-Saro Wiwa Polytechnic \\ Bori, Nigeria
}

\begin{abstract}
Correspondence: Eluozo SN, Department of Civil Engineering College of Engineering, Gregory University Uturu, Nigeria,
\end{abstract} Email Soloeluozo2013@hotmail.com

Received: July 25, 2017 | Published: January 23, 2018

\section{Introduction}

It has been observed that anisotropic nature of rocks is assumed to be caused by disparity in their petrography (mineralogy, texture and micro-structures) including physical properties. These variations have been revealed to occur even in locations where there are only a few centimetres apart on most outcrops. Furthermore, comparable rock types in most localities may not yield the same engineering properties and therefore may not be appropriate for the same use. This condition has express in confirmatory tests on rocks that require lots of test samples and are therefore very expensive, time consuming and tedious. ${ }^{1,2}$ Bulk density and porosity are two of the physical properties that have been observed to be imperative parameters that affect the mechanical properties, particularly Uniaxial Compressive Strength (UCS), base on the factors it is noted to affect the depositions of crystalline rocks. Slight variations in these parameters, particularly porosity, have been discovered to correspond to significant variations in UCS. ${ }^{3-6}$ Studies has express that Porosity of a crystalline rock is the sum of micro-fractures, intra-granular pores and fluid inclusions..$^{7-10}$ Base on these facts Researchers were observed to take porosity of crystalline rocks for granted, by not testing for it, these were note for the facts that the result are normally extremely low values, whereas a slight disparity in this parameters can lead to important variation in UCS which can cause serious disruption of engineering designs. The establishments of a relationship between the two significant parameters of bulk density and porosity have definitely provided a way out of the likely impasse. This condition may always may also lead to a reduction in the cost and time required to test for them during investigation as the bulk density (which is an necessary test parameter) can be used to approximate the porosity of the rock. Moreso, such assessments make it possible to identify areas that require further survey, as well as to demarcate those that could possibly cause a future failure of engineering structures. The rocks of this complex have been variously classified by ${ }^{2,5-9,11}$ classified the rocks as (a) the gneiss-migmatitequartzite complex; (b) the schist belts which are low to medium grade supracrustal and meta-igneous rocks; (c) the Pan African granitoids (Older Granites) and other related rocks such as charnockitic rocks and syenites; and (d) minor felsic and mafic intrusive

\section{Materials and method}

Standard laboratory experiment where performed to determine bulk density and porosity of the different formation, the soil strata were collected in sequences base on the structural deposition at different locations, this samples collected at different location generated variation at different depth producing different values for bulk density and porosity the experimental result are applied for thorough analysis.

\section{Result and discussion}

Results and discussion are presented in tables including graphical representation (Table 1) for bulk Density and porosity stated below. The study express the relationship between bulk density and porosity, the study monitor (Table 2) it at different location as it observed is expressing on the trend showing bulk density influence and the degree of porosity (Table 3 ) at different depositions. Figure 1 show how the bulk density developed fluctuation thus recorded its values between 2.56-2.68 and finally maintained linear (Table 4) homogeneous setting from $2.6-3 \mathrm{~m}$, while porosity decrease in (Table 5) heterogeneous setting between $0.27-0.18$ at $0.2-3 \mathrm{~m}$, (Figure 2) developed oscillation between $0.2-2.5 \mathrm{~m}$ and recorded $2.5-2.63$ while porosity (Table 6 ) recorded $0.23-0.17$ thus increase linearly from $3-5 \mathrm{~m}$, (Figure 3 ) maintained similar condition as bulk density from the its vacillation expressed it trend between 2.52-2.64 while porosity obtained $0.22-0.27$ respectively, (Figure 4 ) the bulk density 
fluctuated and obtained 2.72-2.65, while that of porosity developed $0.12-0.19$, Figure 5 express similar condition and obtained 2.512.64, while porosity (Table 7) generated $0.28-0.27$, Figure 6 express oscillation between $0.2-2.5$ and obtained 2.54-2.68, while porosity developed 0.27-0.18, (Figure 7) maintained light fluctuation (Table 8) thus obtained 2.5-2.63, while that of porosity generated $0.23-0.17$, (Figure 8 ) in the same vein obtained 2.57-2.64 while that of porosity maintained 0.22-0.27, Figure 9 express fluctuation across the depth expressing vacillation (Table 9) and obtained 2.71-2.65 while that of porosity generated $0.12-0.19$, Figure 10 express vacillation across the depth developed 2.51-2.58, while that of porosity generate 0.28 0.26 , the study has monitor bulk density (Table 10) relating it porosity of the soil and determine the behaviour of both parameters in terms application for engineering works.

Table I Bulk density and porosity at different depth

\begin{tabular}{lll}
\hline Depth $[\mathrm{m}]$ & Bulk density & Porosity \\
\hline 0.2 & 2.54 & 0.27 \\
0.4 & 2.52 & 0.28 \\
0.8 & 2.54 & 0.28 \\
1 & 2.58 & 0.25 \\
1.2 & 2.61 & 0.24 \\
1.4 & 2.61 & 0.23 \\
1.6 & 2.61 & 0.21 \\
1.8 & 2.62 & 0.2 \\
2 & 2.64 & 0.19 \\
2.5 & 2.66 & 0.18 \\
3 & 2.88 & 0.18 \\
4 & 2.68 & 0.18 \\
5 & 2.68 & 0.18 \\
\hline
\end{tabular}

Table 2 Bulk density and porosity at different depth

\begin{tabular}{lll}
\hline Depth [m] & Bulk density & Porosity \\
\hline 0.2 & 2.5 & 0.23 \\
0.4 & 2.51 & 0.28 \\
0.8 & 2.54 & 0.29 \\
1 & 2.56 & 0.25 \\
1.2 & 2.57 & 0.23 \\
1.4 & 2.57 & 0.19 \\
1.6 & 2.45 & 0.19 \\
1.8 & 2.45 & 0.19 \\
2 & 2.44 & 0.18 \\
2.5 & 2.62 & 0.17 \\
3 & 2.52 & 0.17 \\
4 & 2.62 & 0.17 \\
5 & 2.63 & 0.17 \\
\hline
\end{tabular}

Table 3 Bulk density and porosity at different depth

\begin{tabular}{lll}
\hline Depth [m] & Bulk density & Porosity \\
\hline 0.2 & 2.52 & 0.22 \\
0.4 & 2.53 & 0.24 \\
0.8 & 2.53 & 0.25 \\
1 & 2.55 & 0.26 \\
1.2 & 2.56 & 0.27 \\
1.4 & 2.57 & 0.27 \\
1.6 & 2.59 & 0.28 \\
1.8 & 2.6 & 0.27 \\
2 & 2.6 & 0.27 \\
2.5 & 2.61 & 0.27 \\
3 & 2.62 & 0.26 \\
4 & 2.63 & 0.27 \\
5 & 2.64 & 0.27 \\
\hline
\end{tabular}

Table 4 Bulk density and porosity at different depth

\begin{tabular}{lll}
\hline Depth [m] & Bulk density & Porosity \\
\hline 0.2 & 2.71 & 0.12 \\
0.4 & 2.7 & 0.13 \\
0.8 & 2.68 & 0.15 \\
1 & 2.66 & 0.16 \\
1.2 & 2.57 & 0.18 \\
1.4 & 2.58 & 0.19 \\
1.6 & 2.1 & 0.23 \\
1.8 & 2.11 & 0.18 \\
2 & 2.11 & 0.18 \\
2.5 & 2.62 & 0.18 \\
3 & 2.63 & 0.19 \\
4 & 2.64 & 0.19 \\
5 & 2.65 & 0.19 \\
\hline
\end{tabular}

Table 5 Bulk density and porosity at different depth

\begin{tabular}{lll}
\hline Depth $[\mathrm{m}]$ & Bulk density & Porosity \\
\hline 0.2 & 2.51 & 0.28 \\
0.4 & 2.5 & 0.28 \\
0.8 & 2.52 & 0.26 \\
$\mathrm{I}$ & 2.52 & 0.24 \\
1.2 & 2.53 & 0.23 \\
1.4 & 2.55 & 0.21 \\
1.6 & 2.56 & 0.21 \\
1.8 & 2.57 & 0.18 \\
2 & 2.54 & 0.19 \\
\hline
\end{tabular}


Table Continued..

\begin{tabular}{lll}
\hline Depth [m] & Bulk density & Porosity \\
\hline 2.5 & 2.54 & 0.2 \\
3 & 2.54 & 0.19 \\
4 & 2.63 & 0.27 \\
5 & 2.64 & 0.27 \\
\hline
\end{tabular}

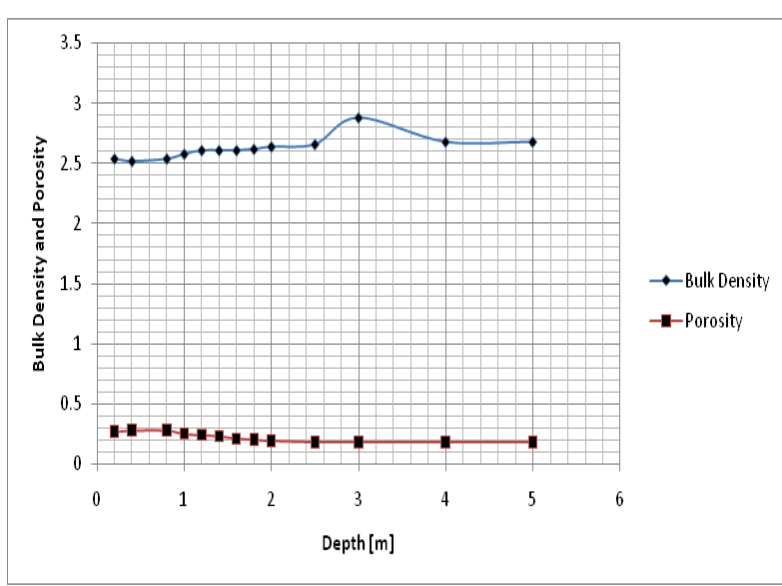

Figure I Bulk density and porosity at different depth.

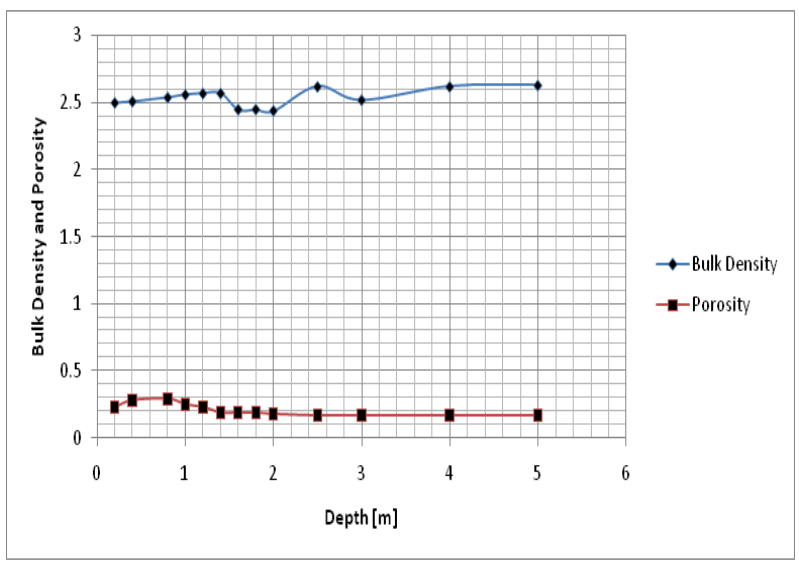

Figure 2 Bulk density and porosity at different depth.

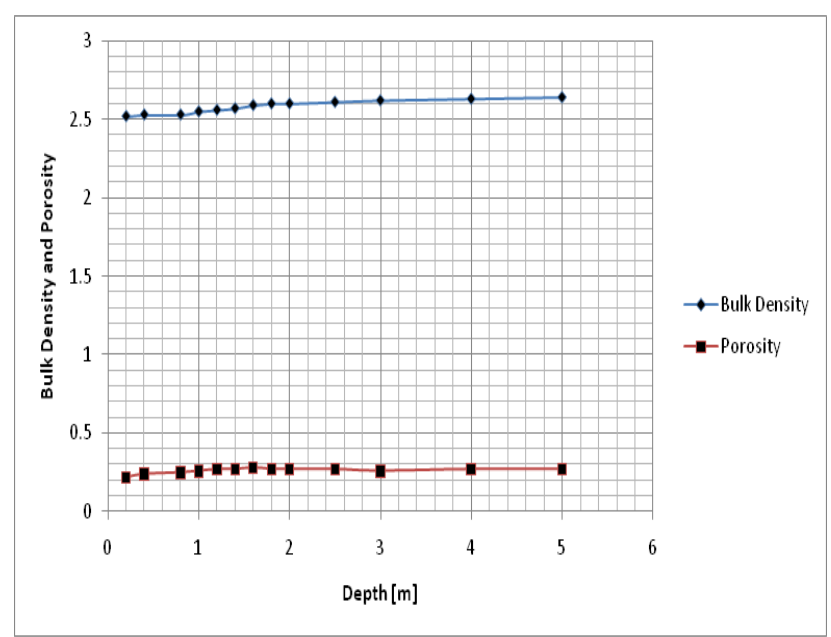

Figure 3 Bulk density and porosity at different depth.

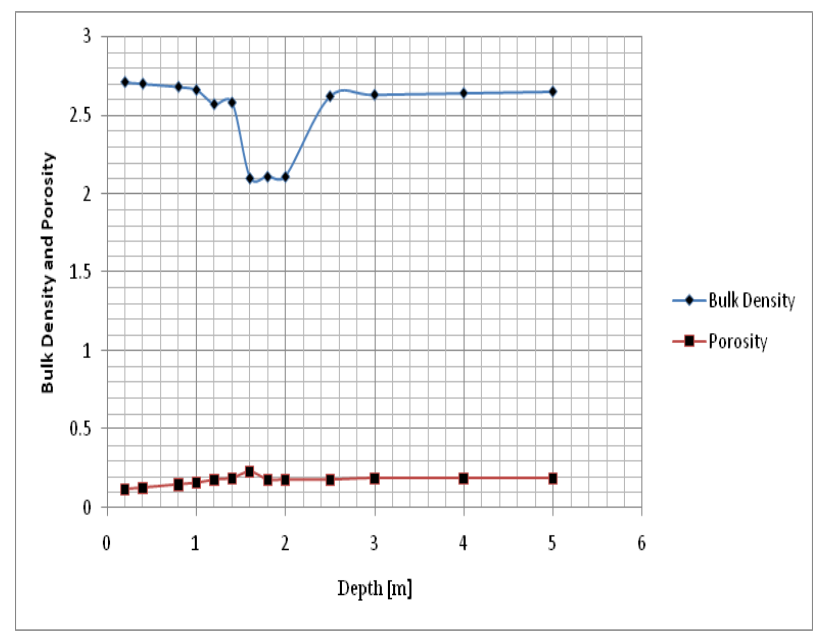

Figure 4 Bulk density and porosity at different depth.

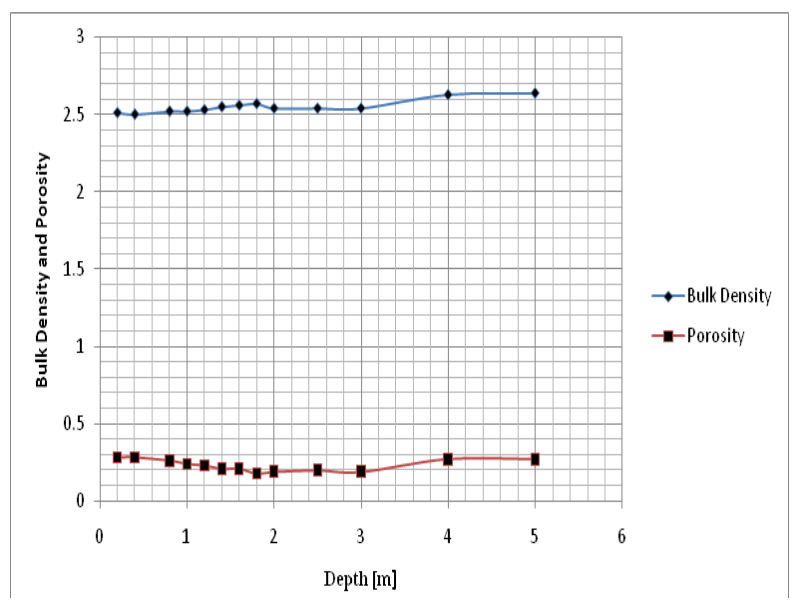

Figure 5 Bulk density and porosity at different depth.

Table 6 Bulk density and porosity at different depth

\begin{tabular}{lll}
\hline Depth [m] & Bulk density & Porosity \\
\hline 0.2 & 2.54 & 0.27 \\
0.4 & 2.52 & 0.28 \\
0.8 & 2.54 & 0.28 \\
1 & 2.58 & 0.25 \\
1.2 & 2.61 & 0.24 \\
1.4 & 2.61 & 0.23 \\
1.6 & 2.61 & 0.21 \\
1.8 & 2.62 & 0.2 \\
2 & 2.64 & 0.19 \\
2.5 & 2.66 & 0.18 \\
3 & 2.88 & 0.18 \\
4 & 2.68 & 0.18 \\
5 & 2.68 & 0.18 \\
\hline
\end{tabular}


Table 7 Bulk density and porosity at different depth

\begin{tabular}{lll}
\hline Depth [m] & Bulk density & Porosity \\
\hline 0.2 & 2.5 & 0.23 \\
0.4 & $2.5 \mathrm{I}$ & 0.28 \\
0.8 & 2.54 & 0.29 \\
$\mathrm{I}$ & 2.56 & 0.25 \\
$\mathrm{I} .2$ & 2.57 & 0.23 \\
$\mathrm{I} .4$ & 2.57 & 0.19 \\
$\mathrm{I} .6$ & 2.45 & 0.19 \\
$\mathrm{I} .8$ & 2.45 & 0.19 \\
2 & 2.44 & 0.18 \\
2.5 & 2.52 & 0.17 \\
3 & 2.52 & 0.17 \\
4 & 2.62 & 0.17 \\
5 & 2.63 & 0.17 \\
\hline
\end{tabular}

Table 8 Bulk density and porosity at different depth

\begin{tabular}{lll}
\hline Depth [m] & Bulk density & Porosity \\
\hline 0.2 & 2.52 & 0.22 \\
0.4 & 2.53 & 0.24 \\
0.8 & 2.53 & 0.25 \\
$\mathrm{I}$ & 2.55 & 0.26 \\
$\mathrm{I} .2$ & 2.56 & 0.27 \\
$\mathrm{I} .4$ & 2.57 & 0.27 \\
$\mathrm{I} .6$ & 2.59 & 0.28 \\
$\mathrm{I} .8$ & 2.6 & 0.27 \\
2 & 2.6 & 0.27 \\
2.5 & $2.6 \mathrm{I}$ & 0.27 \\
3 & 2.62 & 0.26 \\
4 & 2.63 & 0.27 \\
5 & 2.64 & 0.27 \\
\hline
\end{tabular}

Table 9 Bulk density and porosity at different depth

\begin{tabular}{lll}
\hline Depth [m] & Bulk density & Porosity \\
\hline 0.2 & 2.71 & 0.12 \\
0.4 & 2.7 & 0.13 \\
0.8 & 2.68 & 0.15 \\
$\mathrm{I}$ & 2.66 & 0.16 \\
1.2 & 2.57 & 0.18 \\
1.4 & 2.58 & 0.19 \\
1.6 & 2.6 & 0.23 \\
1.8 & $2.6 \mathrm{I}$ & 0.18 \\
2 & $2.6 \mathrm{I}$ & 0.18 \\
\hline
\end{tabular}

Table Continued..

\begin{tabular}{lll} 
Depth [m] & Bulk density & Porosity \\
\hline 2.5 & 2.62 & 0.18 \\
3 & 2.63 & 0.19 \\
4 & 2.64 & 0.19 \\
5 & & 0.19 \\
\hline
\end{tabular}

Table 10 Bulk density and porosity at different depth

\begin{tabular}{|c|c|c|}
\hline Depth [m] & Bulk density & Porosity \\
\hline 0.2 & 2.51 & 0.28 \\
\hline 0.4 & 2.5 & 0.28 \\
\hline 0.8 & 2.52 & 0.26 \\
\hline I & 2.52 & 0.24 \\
\hline 1.2 & 2.53 & 0.23 \\
\hline 1.4 & 2.55 & 0.21 \\
\hline 1.6 & 2.55 & 0.21 \\
\hline 1.8 & 2.56 & 0.18 \\
\hline 2 & 2.57 & 0.18 \\
\hline 2.5 & 2.54 & 0.19 \\
\hline 3 & 2.54 & 0.2 \\
\hline 4 & 2.54 & 0.19 \\
\hline 5 & 2.58 & 0.26 \\
\hline
\end{tabular}

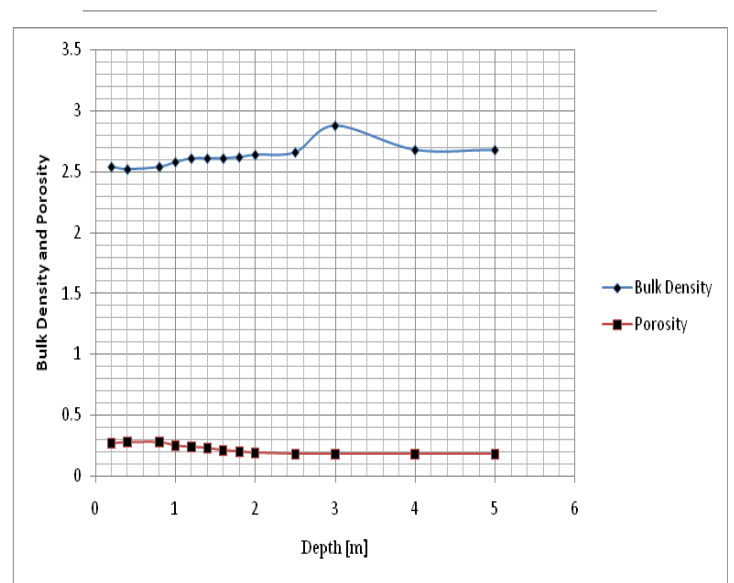

Figure 6 Bulk density and porosity at different depth. 


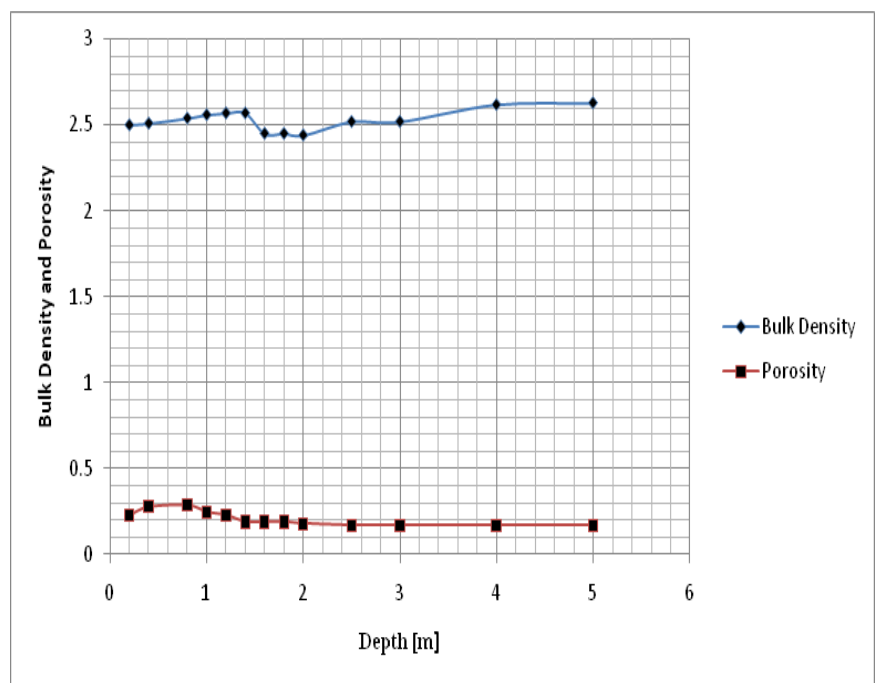

Figure 7 Bulk density and porosity at different depth.

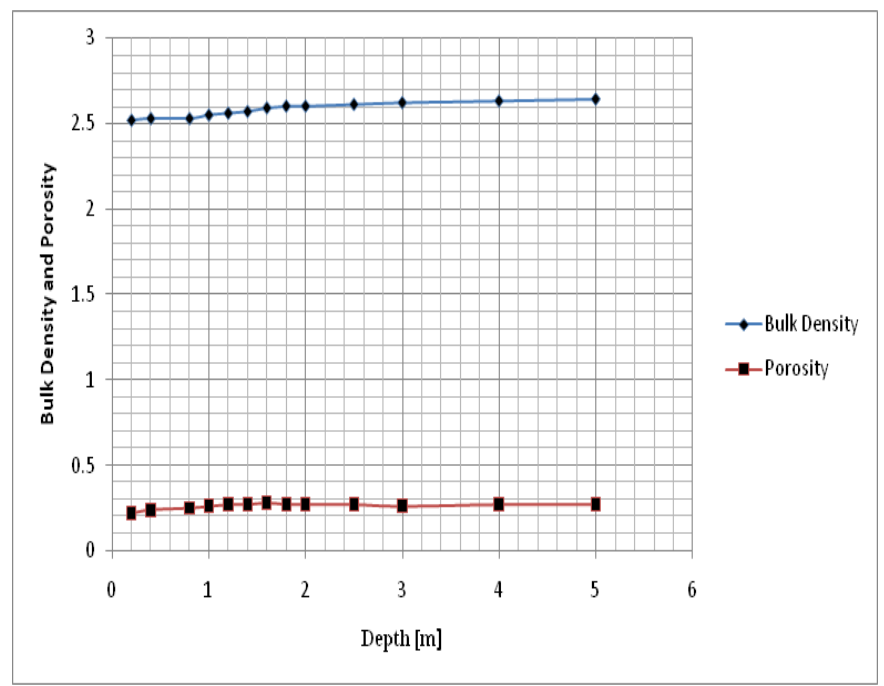

Figure 8 Bulk density and porosity at different depth.

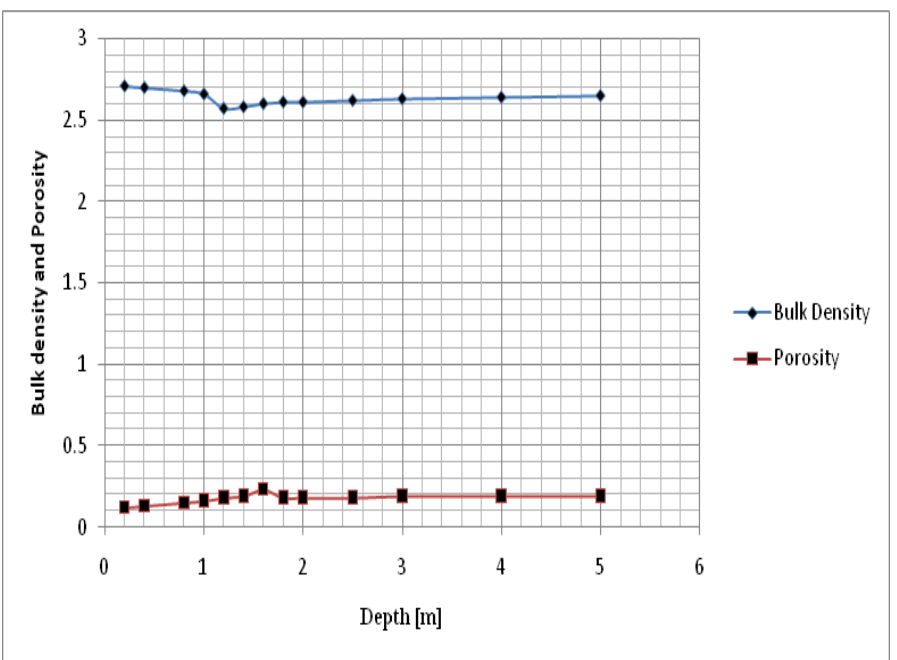

Figure 9 Bulk density and porosity at different depth.

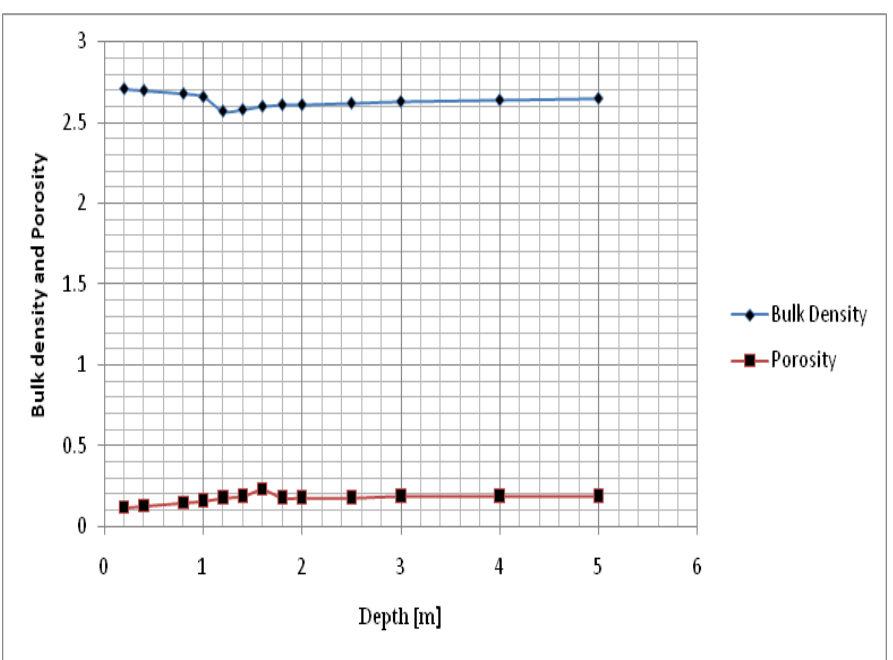

Figure 10 Bulk density and porosity at different depth.

\section{Conclusion}

The soil has been express thoroughly through the rate of its heterogeneity in the lithology, the relationship between bulk density and porosity has been evaluated, the rate of fluctuation between the strata base on its structure, it has express variation observed from the graphical representation of the values, the behaviour of the soil shows that the higher the bulk density the lower the porosity, while in some condition it is vice-versa, the values from this study, it is observed that the higher the bulk density the lower the porosity, these condition express the behaviour of sandy and silty clay formation. The values generated shows the rate of Bulk density and porosity known as two physical properties that have been found to significantly affect the mechanical properties, particularly Uniaxial Compressive Strength (UCS). The study has streamlined the refection of soil heterogeneity in terms of the generated values from both parameters.

\section{Acknowledgements}

None.

\section{Conflict of interest}

The author declares no conflict of interest.

\section{References}

1. Teme SC. The Engineering Geological Significance of the Point-Load Index Tests in Rock Material Strength Evaluation. Nigerian Journal of Mining and Geology. 1983;20(1-2):87-93.

2. Tullborg Eva-Lena, Larson S. Porosity in crystalline rocks: A matter of scale. Engineering Geology. 2006;84(1-2):75-83.

3. Adekoya JA. The Nigerian schist belts: Age and depositional environment implications for associated banded iron formations. Journal Mining Geology. 1996;32:35-46.

4. Adekoya JA, Kehinde Phillips OO, Odukoya AM. Geological distribution of mineral resources in southwest Nigeria. In: Elueze AA, editor. Prospects for investment in mineral resources of Southwestern Nigeria. Nigeria; 2003. p. 1-13.

5. Ademeso OA. Geomechanical Characterization of some Precambrian Basement Complex rocks in Akure and Igarra Areas, Nigeria. Nigeria: A PhD thesis submitted to the Department of Applied Geology of The Federal University of Technology; 2011. 220 p. 
6. Brown ET. Rock characterization, testing and monitoring-ISRM suggested methods. UK: Pergamon Press; 1981. 201 p.

7. James DB. Standard error vs standard error of measurement. shiken: JALT testing and Evaluation SIG newsletter. 1999;3(1):15-19.

8. Odeyemi IB. Lithostratigraphy and structural relationship of the Upper Precambrian metasediments in Igarra area, South-Western Nigeria. Precambrian Geology of Nigeria. Nigeria: Geological Survey of Nigeria, Nigeria; 1988. p. 111-125.
9. Rahaman MA. Recent advances in the study of the basement complex of Nigeria. Precambrian Geology of Nigeria. Nigeria: GSN Publication; 1988. p. 11-43.

10. Rahaman MA. A review of the basement geology of Southwestern Nigeria. In: Kogbe CA, editor. Nigeria: Geology of Nigeria, Elizabeth Publishing Co Nigeria; 1976. p. 41-58.

11. Gates WCB, West PK. Estimating the unconfined Compressive Strength of Vessicular Basalts via Bulk Specific Gravity of the Rock Sample. The $42^{\text {nd }}$ U.S. Rock Mechanics Symposium. 2008. 